(100-441) and Tc1-intron (321-566) (numbers from genomic sequence). The probe used for $g f p$ was gfp 1 (19-319) (numbered from ATG). Details of the probes used for analyses of Tc3 and Tc5 dsRNA are available on request. $5^{\prime}$-RACE analyses used the SmartII kit (Clontech), SuperScriptII reverse transcriptase (GibcoBRL) and Pwo DNA polymerase. $\mathrm{S} 100 \mathrm{H}$ fractions were prepared as described in ref. 25. Standard procedures were used for primer-extension analyses. Sequences of all primers used are available on request.

Quantification of protected fragments (RNase protection assays) was performed using ImageQuant software.

\section{Transgenic lines}

The chimaeric $g f p$ reporter plasmids were produced by inserting various fragments into plasmid pAZ132 (ref. 26). Plasmid pAZ1 (TIR fusion) contained nucleotides 1-54 of Tc1 (genomic sequence) in the sense orientation in the SgrAI site. Plasmid pAZ4 (unc-22 fusion) contained nucleotides 11,137-11,190 of unc-22 (spliced sequence) in the sense orientation in the SgrAI site. Plasmid pAZbb (TIR 3' stop) contained nucleotides 1-54 of $\mathrm{Tc} 1$ in the sense orientation in the BsaBI site. To prevent transgene silencing due to the presence of high transgene copy numbers ${ }^{27}$, low-copy-number transgenic lines were generated by ballistic transformation ${ }^{28}$ using a heptamer adaptor (Bio-Rad).

Transformants were generated in $u n c-119(d p 38)$ worms. All lines were selected and they were analysed for GFP expression on both wild-type (OP50) and mut-16 dsRNA food. Worms were grown under these conditions for two generations. Lines not expressing GFP under any of these conditions were discarded; these included six TIR fusion lines, two unc22 fusion lines and ten TIR 3 ' stop lines. By DNA blot analyses (carried out according to standard procedures), transgene copy number was determined using SacII- and BglIIdigested genomic DNA and $g f p$ - and pBlueScript-specific probes. Crosses using pkIs 1660 showed that all three transgene copies in this line reside at one locus and segregate in a mendelian manner. However, the transgenes can be lost (presumably due to recombination), as is apparent from the presence of worms with an unc-119 phenotype (PCR analyses confirmed transgene loss in these worms). Transgene loss is not uncommon for ballistic-generated transformants and varies for the lines as follows: pkIs1660, 1\%; pkIs1661, 10\%; pkIs1662, 10\%; pkIs1663, 2\%; pkIs1664, 80\%; pkIs1665, 0\%; pkIs1666, 1\%; pkIs1667, 50\%; pkIs1668, 0\%; pkIs1669, 0\%; pkIs1671, 0\%; and pkIs1672, 0\%.

Interestingly, transgene loss strongly increases upon crossing to strains defective in transposon silencing ( $m u t-7$ and $p k 732$ but not $r d e-1$ ); this transgene loss is not dependent on the presence of the Tc1 TIR sequence, as it also occurs upon crossing mut-7 to pkIs 1665 , an $u n c-22$ fusion line.

\section{dsRNAs}

Plasmids for dsRNA production in E. coli comprised pTS302 dsRNA ${ }^{11}$ (for unc-22) and pTS303 (containing nucleotides 1-441 of the Tc1 genomic sequence inserted into the SmaI site of vector L4440 (ref. 29)). E. coli expressing mut-16 dsRNA were obtained from well number $17 \mathrm{C} 5$ of the C. elegans feeding library ${ }^{30}$.

Received 28 August; accepted 23 September 2003; doi:10.1038/nature02107.

1. Emmons, S. W., Yesner, L., Ruan, K. S. \& Katzenberg, D. Evidence for a transposon in Caenorhabditi elegans. Cell 32, 55-65 (1983).

2. Ketting, R. F., Haverkamp, T. H., van Luenen, H. G. \& Plasterk, R. H. Mut-7 of C. elegans, required fo transposon silencing and RNA interference, is a homolog of Werner syndrome helicase and RNaseD. Cell 99, 133-141 (1999)

3. Tabara, H. et al. The rde-1 gene, RNA interference, and transposon silencing in C. elegans. Cell 99, 123-132 (1999).

4. Fischer, S. E. J., Wienholds, E. \& Plasterk, R. H. A. Continuous exchange of sequence information between dispersed Tcl transposons in the C. elegans genome. Genetics 164, 127-134 (2003).

5. Vos, J. C., De Baere, I. \& Plasterk, R. H. Transposase is the only nematode protein required for in vitro transposition of Tc1. Genes Dev. 10, 755-761 (1996).

6. Plasterk, R. H. RNA silencing: the genome's immune system. Science 296, 1263-1265 (2002).

7. Sijen, T. et al. Transcriptional and posttranscriptional gene silencing are mechanistically related. Curr. Biol. 11, 1-20 (2001)

8. Aroian, R. V., Field, C., Pruliere, G., Kenyon, C. \& Alberts, B. M. Isolation of actin-associated proteins from Caenorhabditis elegans oocytes and their localization in the early embryo. EMBO J. 16, 1541-1549 (1997).

9. Knight, S. W. \& Bass, B. L. The role of RNA editing by ADARs in RNAi. Mol. Cell 10, 809-817 (2002)

10. Bernstein, E., Caudy, A. A., Hammond, S. M. \& Hannon, G. J. Role for a bidentate ribonuclease in the initiation step of RNA interference. Nature 409, 363-366 (2001).

11. Sijen, T. et al. On the role of RNA amplification in dsRNA-triggered gene silencing. Cell 107, 465-476 (2001).

12. Ambros, V., Lee, R. C., Lavanway, A., Williams, P. T. \& Jewell, D. MicroRNAs and other tiny endogenous RNAs in C. elegans. Curr. Biol. 13, 807-818 (2003).

13. Caudy, A. A. et al. A micrococcal nuclease homologue in RNAi effector complexes. Nature $\mathbf{4 2 5}$, 411-414 (2003).

14. Tabara, H., Yigit, E., Siomi, H. \& Mello, C. C. The dsRNA binding protein RDE-4 interacts with RDE-1, DCR-1, and a DExH-box helicase to direct RNAi in C. elegans. Cell 109, 861-871 (2002).

15. Vastenhouw, N. L. et al. A genome-wide screen identifies 27 genes involved in transposon silencing in C. elegans. Curr. Biol. 13, 1311-1316 (2003).

16. Tijsterman, M., Ketting, R. F., Okihara, K. L., Sijen, T. \& Plasterk, R. H. RNA helicase MUT-14- dependent gene silencing triggered in C. elegans by short antisense RNAs. Science 295, 694-697 (2002).

17. Zamore, P. D., Tuschl, T., Sharp, P. A. \& Bartel, D. P. RNAi: double-stranded RNA directs the ATP-dependent cleavage of mRNA at 21 to 23 nucleotide intervals. Cell 101, 25-33 (2000).

18. English, J. J., Mueller, E. \& Baulcombe, D. C. Suppression of virus accumulation in transgenic plants exhibiting silencing of nuclear genes. Plant Cell 8, 179-188 (1996).

19. Sijen, T., Wellink, J., Hiriart, J. B. \& Van Kammen, A. RNA-mediated virus resistance: role of repeated transgenes and delineation of targeted regions. Plant Cell 8, 2277-2294 (1996).

20. Volpe, T. A. et al. Regulation of heterochromatic silencing and histone $\mathrm{H} 3$ lysine- 9 methylation by RNAi. Science 297, 1833-1837 (2002).

21. Reinhart, B. J. \& Bartel, D. P. Small RNAs correspond to centromere heterochromatic repeats. Science 297, 1831 (2002)

22. Schramke, V. \& Allshire, R. Hairpin RNAs and retrotransposon LTRs effect RNAi and chromatinbased gene silencing. Science 301, 1069-1074 (2003).

23. Fire, A. et al. Potent and specific genetic interference by double-stranded RNA in Caenorhabditis elegans. Nature 391, 806-811 (1998).

24. Parrish, S., Fleenor, J., Xu, S., Mello, C. \& Fire, A. Functional anatomy of a dsRNA trigger. Differential requirement for the two trigger strands in RNA interference. Mol. Cell 6, 1077-1087 (2000).

25. Hammond, S. M., Bernstein, E., Beach, D. \& Hannon, G. J. An RNA-directed nuclease mediates posttranscriptional gene silencing in Drosophila cells. Nature 404, 293-296 (2000).

26. Praitis, V., Casey, E., Collar, D. \& Austin, J. Creation of low-copy integrated transgenic lines in Caenorhabditis elegans. Genetics 157, 1217-1226 (2001).

27. Kelly, W. G. \& Fire, A. Chromatin silencing and the maintenance of a functional germline in Caenorhabditis elegans. Development 125, 2451-2456 (1998).

28. Wilm, T., Demel, P., Koop, H. U., Schnabel, H. \& Schnabel, R. Ballistic transformation of Caenorhabditis elegans. Gene 229, 31-35 (1999).

29. Timmons, L. \& Fire, A. Specific interference by ingested dsRNA. Nature 395, 854 (1998).

30. Fraser, A. G. et al. Functional genomic analysis of C. elegans chromosome 1 by systematic RNA interference. Nature 408, 325-330 (2000).

Acknowledgements We thank R. Ketting for help in experiments and discussions, and E. Berezikov for help with the ballistic transformations. We acknowledge S. Fischer,

N. Vastenhouw, V. Robert, E. Cuppen, R. May and M. Joosten for helpful discussions or for critically reading the manuscript. This work was supported by a VIDI fellowship from the Dutch Science Foundation (NWO) to T.S.

Competing interests statement The authors declare that they have no competing financial interests.

Correspondence and requests for materials should be addressed to R.H.A.P.

(plasterk@niob.knaw.nl).

\section{corrigendum}

\section{An NS3 protease inhibitor with antiviral effects in humans infected with hepatitis C virus}

Daniel Lamarre, Paul C. Anderson, Murray Bailey, Pierre Beaulieu, Gordon Bolger, Pierre Bonneau, Michael Bös, Dale R. Cameron, Mireille Cartier, Michael G. Cordingley, Anne-Marie Faucher, Nathalie Goudreau, Stephen H. Kawai, George Kukolj, Lisette Lagacé, Steven R. Laplante, Hans Narjes, Marc-André Poupart, Jean Rancourt, Roel E. Sentjens, Roger St George, Bruno Simoneau, Gerhard Steinmann, Diane Thibeault, Youla S. Tsantrizos, Steven M. Weldon, Chan-Loi Yong \& Montse Llinàs-Brunet

Nature 426, 186-189 (2003).

In this Letter, the 'Competing interests statement' should be corrected to: 'The authors declare competing financial interests: R.E.S. was the clinical investigator and received an honorarium from Boehringer Ingelheim. All the other authors are or were employees of Boehringer Ingelheim.. 